\title{
Implementation of a cleaner production program in a Brazilian wooden furniture factory
}

\author{
Carlos Henrique Ribeiro Massote ${ }^{\mathrm{a}, *}$, Auxiliadora Maria Moura Santi ${ }^{\mathrm{b}}$ \\ ${ }^{a}$ E2 Environmental Consulting Ltd., Belo Horizonte, 35400-000 Ouro Preto, Minas Gerais, Brazil \\ ${ }^{\mathrm{b}}$ Federal University of Ouro Preto, Department of Industrial Engineering, Ouro Preto, Brazil
}

\section{A R T I C L E I N F O}

\section{Article history:}

Received 31 May 2011

Received in revised form

23 July 2012

Accepted 3 September 2012

Available online 14 September 2012

\section{Keywords:}

Cleaner production (CP)

Optimization of manufacturing system

Environmental management

Furniture industry (Brazil)

\begin{abstract}
A B S T R A C T
The cleaner production (CP) methodology was implemented in an industry in the furniture sector as a management tool for achieving eco-efficiency and obtaining environmental and economic benefits. Based on the application of CP principles to a Brazilian furniture factory, audits of raw material and water consumption were proposed for the manufacturing divisions of this company and for the generation of solid waste and effluents. Tools were implemented for assessing material flow, aimed at the development and analysis of the mass balances of the processes involved. These tools supported the identification, evaluation and implementation of actions addressing five $\mathrm{CP}$ opportunities that were preventative in nature, resulting in reduced generation of solid wastes and liquid effluents and a decrease in the inflow of raw material inputs and water. A saving of $66 \%$ in water and $3 \%$ in raw materials consumption was obtained, and there had been a reduction of $23 \%$ in the solid waste and $93 \%$ in the effluents generation. The production cost per unit was on average US\$ 0.14 lower than before. The economy of wood will prevent the cutting of around 3900 adult pine trees and the emission of 13,100 $\mathrm{kg}$ of carbon dioxide equivalent in the waste and raw materials transport, which is an additional environmental gain.
\end{abstract}

(C) 2013 Elsevier Ltd. All rights reserved.

\section{Introduction}

It has been increasingly observed that the use of tools or techniques for the prevention or reduction of the generation of wastes, effluents and emissions in industrial operations, such as the implementation of cleaner production (CP) methodology, are becoming a priority. This is not only due to progressive environmental awareness in our global society, with a consistent demand for environmentally friendly products, but also to the growing pressure on finite natural resources imposed by corporations, reducing the availability of these resources and, consequently, impacting costs for the purchase of raw materials and water as well as for the disposal of emitted effluents and waste.

The CP methodology proposed by United Nations Environment Program (UNEP) together with the United Nations Industrial Development Organization (UNIDO) is a pollution prevention program based in the waste management and in the misuse of energy and materials (UNIDO/UNEP, 1991).

The CP methodology is defined as "the continuous application of a preventive environmental strategy that is integrated to processes,

\footnotetext{
* Corresponding author. Tel.: +55 3188410289.

E-mail address: massote.carlos@gmail.com (C.H. Ribeiro Massote).
}

products and services in order to increase the eco-efficiency and to reduce the risks to humans and the environment. The $\mathrm{CP}$ can be applied to processes used in any sector of the economy, in the products themselves or services" (CETESB/UNEP, 2002).

Brazilian furniture manufacturing is an important sector of the national economy; its products are mainly fabricated with wood, which comes from planted pine forests. Using wood as raw material, the furniture industry generates wood wastes that are proportional to the input of wood in the production processes (Daian and Ozarska, 2009). The betterment of operational practices, the technological changes and the reduction of waste amounts through reuse, recycling and remanufacture already represent a move toward a cleaner production (Ehrenfeld and Gertler, 1997) and are aspects that must be considered to identify the CP opportunities that will make the wood consumption more rational and sustainable (Eshun et al., 2012). Moreover, technological innovation in furniture manufacturing had became very important for the competitiveness and the maintenance of that sector (Vickery et al., 1997), and a good way to improve its environmental and financial conditions is to carry out CP programs (Nascimento, 2009; Riul, 2010; Oliveira and Araújo, 2009).

This paper reports the experience of implementing a CP program in the paneling division of the furniture factory Mod Line Corporate Solutions, Ltd., which counts for $15 \%$ of Brazilian market 
of doors and partition panels (Mod Line Corporate Solutions Ltd., Personal communication).

As it commercializes several corporate products, "from floor to roof", the Mod Line is characterized by the separation of manufacturing processes into divisions; among them, the carpentry, metallurgy, raised floor, surface chemical treatment, electrostatic painting, profiling, paneling, internal assembly, finishing and upholstery divisions are the most relevant.

The implementation of a CP program in the paneling division, which is the Mod Line factory's most important division, enabled a decrease in wood, packing (corrugated cardboard, plastic tape) and water consumption as well as in solid waste.

As the manufacturing processes in the paneling division is similar to that of almost all wooden furniture factories, since they use the same raw materials, adopt the same operating procedures and generate the same type of waste, the results obtained in Mod Line factory can motivate other wooden furniture industries to put $\mathrm{CP}$ practices into action in their production units.

\section{Study methodology and development}

The CP program carried out in the furniture factory Mod Line was based on the methodology recommended by UNEP and UNIDO (UNIDO/UNEP, 1991). The methodological sequence sought to reproduce the environmental diagnostic and prognostic phases of the National Center for Clean Technology (CNTL), which include five stages: (1) planning and organization, (2) pre-evaluation, (3) evaluation, (4) feasibility studies and (5) implementation; those stages are subdivided into twenty steps. The CNTL is located in the Industries Federation of Rio Grande do Sul (FIERGS) together with the Regional Department of the National Service of Industrial Learning (SENAI-Rio Grande do Sul) since 1995 (UNIDO/UNEP, 1995; Germany Federal Environment Ministry, 1997; Schnitzer, 1995).

This paper presents the actions performed within the first 18 months after the start of the CP program.

\subsection{Planning and organization stage}

To enlist support among the company's upper management and employees who would be involved in the program, comprising the $\mathrm{CP}$ team, several lectures were given, aimed at raising awareness about the importance of environmental issues and the benefits of implementing a $\mathrm{CP}$ program in the company. In the preliminary stages, barriers to be overcome during development of the $\mathrm{CP}$ program were identified, and in conjunction with the company's upper management, the general objective of the $\mathrm{CP}$ program was defined to improve the environmental and economic performance of the industrial plant.

\subsection{Pre-evaluation stage}

Concerning the scope of the $\mathrm{CP}$ program, it was decided that, initially, one of the divisions of the company would be selected for implementation. The choice of the division was based on prognostic results and reports from the Eco-Inspector Plus program, which aims to indicate the areas or manufacturing divisions with the greatest potential for environmental and economic responses to the implementation of $\mathrm{CP}$ methodology. The Eco-Inspector Plus program was developed by the Northwestern Switzerland University of Applied Sciences (FHNW) (Eco Inspector, 2006), and it was made available by the Sustainable Industrial Production Center (CEPIS), located in the State of Paraíba, Brazil. The CEPIS serves as a reference center on $\mathrm{CP}$ for the northeastern region of Brazil, resulting from Brazilian Micro and Small Business Support Service
(SEBRAE) collaboration in the State of Paraiba, in partnership with the Swiss State Secretariat on the Economy (SECO) and with the technical support of FHNW (CEPIS-Sustainable Production Center, 2007). The Eco-Inspector Plus software enables a semiquantitative evaluation of the production process based on the knowledge of managers and factory division supervisors, who were asked to make a preliminary analysis of the development of industrial operations, i.e., a quick scan, by selecting the appropriate options for each area in the spreadsheet cells generated by the program. Each option selected may be complemented by comments and explanations of reasons for their selection. The completed spreadsheets and the resulting tables and diagrams supported the selection of processes to be investigated in more detail in the subsequent stages and steps recommended by the $\mathrm{CP}$ methodology.

A meeting with company management was conducted to select the focus for implementing the $\mathrm{CP}$ methodology, and the division in which the $\mathrm{CP}$ program would be implemented was identified. The analysis of the results from the reports generated by the EcoInspector Plus program indicated three divisions with the greatest economic and environmental potential for implementation of a CP program: the raised floor division, the upholstery division and the paneling division. Together with the company management, it was determined that the $\mathrm{CP}$ program would be developed for the paneling division. The following factors were considered in that choice: (1) the paneling division represents $50 \%$ of Mod Line's turnover, (2) doors and partition panels have a small aggregate value, and any lessening of production costs increases their competitiveness in the market, (3) the division's industrial wastewater treatment station (ETEI) had a serious operational problem, and the company management expected that the $\mathrm{CP}$ program could help solving it.

Wood, wood fiber materials and glue are used to produce doors and panels; water is employed in producing adhesive and in cleaning the factory area. Doors and panels are made from two flat sheets of pressed wood fibers, which are glued on the edges to an internal timber frame filled with a honeycomb structure of kraft paper. Finally, doors and panels are packed with a plastic wrap, stacked up on wooden pallets in piles of 34 units and tied with rigid plastic tape.

Moving on to the second stage of the $\mathrm{CP}$ methodology, a global qualitative flowchart, shown in Fig. 1, and another, more detailed, qualitative chart highlighting the processes involved in the paneling division were constructed. Entry data for material inputs and outputs of by-products, waste and effluents at each stage of the paneling division were collected on the "factory floor" (in loco) by measuring the amounts of all raw materials and water used and the amounts of by-products, waste and liquid effluents generated, as the company did not previously have reliable quantitative data.

A member of the $\mathrm{CP}$ team measured the weights of raw materials and waste in balances suited to the quantities; the time required for it varied depending on the amounts consumed or generated, the environmental and economic relevance of each material as well as the degree of its standardization. He also measured the volume of process water and effluents using meters that were placed at strategic points along the production line; the measurements were done fortnightly.

In making the measurements it was taken into account that the process is continuous, its interruptions are occasional and the final products are quite similar to one another. Thus the results are reliable, even though they were obtained employing low-cost techniques.

\subsection{Evaluation stage}

Once the CP program to be implemented in the paneling division had been defined, the third stage of the methodology was 


\begin{tabular}{|c|c|c|}
\hline $\begin{array}{l}\text { Electric power } \\
\text { Compressed air } \\
\text { Phreatic well water } \\
\text { ETEl-treated water } \\
\text { Wooden boards } \\
\text { Duraplac wooden fiber plates } \\
\text { Honeycomb Kraft paper } \\
\text { Wheat flour } \\
\text { Urea formaldehyde resin } \\
\text { Catalyst } \\
\text { Sulfuric acid } \\
\text { Granulated urea } \\
\text { Staples } \\
\text { Filter pads } \\
\text { ETEI chemical products } \\
\text { Shrink plastic } \\
\text { Corrugated cardboard } \\
\text { Plate protection wood fiber } \\
\text { covers } \\
\text { Rigid plastic tape } \\
\text { Wooden beams } \\
\text { Slats } \\
\text { Nails } \\
\text { Teflon } \\
\text { Wooden pallets } \\
\text { Styluses }\end{array}$ & $\begin{array}{l}\text { MANUFACTURING } \\
\text { OF } \\
\text { PANELS } \\
\text { AND } \\
\text { DOORS } \\
\qquad \\
\downarrow\end{array}$ & $\begin{array}{l}\text { Heat } \\
\text { Paneling division effluent } \\
\text { Fine rigid plastic tape (wooden } \\
\text { board pack) } \\
\text { Small slats / small beams (wooden } \\
\text { board packs) } \\
\text { Wooden waste } \\
\text { Waste resin drums } \\
\text { Dry glue } \\
\text { ETEl mud } \\
\text { Wooden pallets (Duraplac plate } \\
\text { packs) } \\
\text { Protective covers (Duraplac plate } \\
\text { packs) } \\
\text { Wood gratings (Duraplac plate } \\
\text { packs) } \\
\text { Rigid plastic tape (Duraplac plate } \\
\text { packs) } \\
\text { Empty catalyst bags } \\
\text { Package plastic } \\
\text { Empty flour bags } \\
\text { Dirty filter pads } \\
\text { Evaporated water } \\
\text { Panel and door sawdust } \\
\text { Surplus shrink plastic } \\
\text { Packaging cardboard } \\
\text { Cardboard rolls (shrink plastic } \\
\text { pack) } \\
\text { Surplus corrugated cardboard } \\
\text { Surplus rigid plastic tape } \\
\text { Cardboard rolls (plastic tape pack) } \\
\text { Waste from wood processing } \\
\text { Wooden pallets (Duraplac plate } \\
\text { packs) } \\
\text { Used plates } \\
\text { Used Teflon }\end{array}$ \\
\hline
\end{tabular}

Fig. 1. Global qualitative flowchart of the paneling division.

initiated with an elaboration of balance sheets for the materials and water used for the entire panel and door manufacturing process in the form of two process flowcharts, one for door manufacturing and another for panel manufacturing. Here, all of the inputs and outputs of material were recorded, and a global balance sheet of materials for the manufacturing process of panels and doors of this division was also made, as shown in Table 1 . In developing the material and water balance sheets, an annual production of 448,800 panels and 76,200 doors was assumed.

In the third stage, the sources and causes of the generation of waste and liquid effluents were identified, and the CP opportunities to be addressed were identified and selected in brainstorming meetings with the CP team, accomplished with the help of flowcharts and material and water balance sheets. The CP opportunities were named for ease of reference; they were grouped in chronological order of implementation, as defined by operational and technological demands and the necessary scope of technical, economic and environmental feasibility studies.

The selected CP opportunities were the following: (1) a reduction in the generation of surplus corrugated cardboard used for the packaging of panels and doors, (2) a reduction in the generation of rigid plastic tape waste from the packaging of panels and doors, (3) the reduction of wood waste from the manufacturing of frames used in the production of doors and dividing panels, (4) reductions in effluent generated for the ETEI of the paneling division and the consumption of chemical products for the treatment of this effluent and (5) the reduction of mud generation at the ETEI of the paneling division.

\subsection{Feasibility studies and the implementation of actions} addressing the CP opportunities

The fourth and fifth stages recommended in the CP methodology were developed sequentially, with the completion of preliminary technical, economic and environmental feasibility studies regarding the previously identified $\mathrm{CP}$ opportunities and the implementation of actions addressing the selected $\mathrm{CP}$ opportunities.

Thereafter, only input and output of materials related to the results of $\mathrm{CP}$ actions, were quantified using the same measurement techniques presented above (item 2.2).

\section{Identification and implementation of actions addressing the $\mathrm{CP}$ opportunities and the results achieved}

Taking into account the specific components of the CP opportunities addressed and the respective solutions adopted, the results obtained for each individually were reported, as highlighted below.

\subsection{Opportunity for reduction in the generation of surplus corrugated cardboard generated in the packaging of panels and doors}

This CP opportunity was identified upon analysis of the procedures conducted by operators during the packaging of doors and dividing panels, where excess waste of corrugated cardboard was observed, because the cardboard is purchased in 
Table 1

General balance of materials for the production of panels and doors, before the implementation of the CP program in the paneling division.

\begin{tabular}{|c|c|c|c|}
\hline \multicolumn{4}{|c|}{ Total annual production considered: 448,800 panels and 76,200 doors } \\
\hline \multicolumn{2}{|l|}{ Input } & \multicolumn{2}{|l|}{ Output } \\
\hline Materials and inputs & Amount & Waste and effluents & Amount \\
\hline Phreatic well water/treated & $310 \mathrm{~m}^{3}$ & Effluent & $200 \mathrm{~m}^{3}$ \\
\hline Wooden boards & $1,856,059 \mathrm{~kg}$ & Fine rigid plastic tape & $362 \mathrm{~kg}$ \\
\hline Duraplac plates & $7,390,062 \mathrm{~kg}$ & Small slats & $4535 \mathrm{~kg}$ \\
\hline Kraft honeycomb cardboard & $386,219 \mathrm{~kg}$ & Small beams & $6594 \mathrm{~kg}$ \\
\hline Wheat flour & $94,512 \mathrm{~kg}$ & Wood waste & $504,957 \mathrm{~kg}$ \\
\hline Urea formaldehyde resin & $347,606 \mathrm{~kg}$ & Waste resin drums & $1996 \mathrm{~kg}$ \\
\hline Catalyst & $17,294 \mathrm{~kg}$ & Dry glue & $5280 \mathrm{~kg}$ \\
\hline Sulfuric acid & $142 \mathrm{~kg}$ & Wooden pallets & $101,170 \mathrm{~kg}$ \\
\hline Granulated urea & $133 \mathrm{~kg}$ & Protective covers & $63,157 \mathrm{~kg}$ \\
\hline Staples & $365 \mathrm{~kg}$ & Wood gratings & $31,702 \mathrm{~kg}$ \\
\hline Filter pads & $213 \mathrm{~kg}$ & Thick rigid plastic tape & $1295 \mathrm{~kg}$ \\
\hline ETEI chemical products & $356 \mathrm{~kg}$ & Empty catalyst bags & $100 \mathrm{~kg}$ \\
\hline Shrink plastic & $85,215 \mathrm{~kg}$ & Package plastic & $299 \mathrm{~kg}$ \\
\hline Corrugated cardboard & $39,160 \mathrm{~kg}$ & Empty flour bags & $323 \mathrm{~kg}$ \\
\hline Protective covers & $84,073 \mathrm{~kg}$ & ETEI mud & $45,236 \mathrm{~kg}$ \\
\hline Rigid plastic tape & $2383 \mathrm{~kg}$ & Dirty filter pads & $213 \mathrm{~kg}$ \\
\hline Wooden beams & $90,911 \mathrm{~kg}$ & Evaporated water & $15 \mathrm{~m}^{3}$ \\
\hline Slats & $238,808 \mathrm{~kg}$ & Panel/door sawdust & $661,584 \mathrm{~kg}$ \\
\hline \multirow[t]{7}{*}{ Nails } & $1710 \mathrm{~kg}$ & Surplus shrink plastic & $197 \mathrm{~kg}$ \\
\hline & & Cardboard packaging & $920 \mathrm{~kg}$ \\
\hline & & Cardboard rolls for plastic & $13,510 \mathrm{~kg}$ \\
\hline & & Surplus corrugated cardboard & $499 \mathrm{~kg}$ \\
\hline & & Surplus rigid tape & $11 \mathrm{~kg}$ \\
\hline & & Cardboard rolls for tape & $24 \mathrm{~kg}$ \\
\hline & & Waste from wood processing & $5607 \mathrm{~kg}$ \\
\hline Total material (kg) & $10,635,225 \mathrm{~kg}$ & Total waste (kg) & $1,449,572 \mathrm{~kg}$ \\
\hline Total water $\left(\mathrm{m}^{3}\right)$ & $310 \mathrm{~m}^{3}$ & Total effluent $\left(\mathrm{m}^{3}\right)$ & $215 \mathrm{~m}^{3}$ \\
\hline
\end{tabular}

the form of reels wider than the panels and doors and is cut to a length greater than that of either product. It was investigated whether there would be any operational problems if the cardboard were purchased at the exact width of the panels and doors and cut exactly to the same length as those products, so as to avoid cardboard waste, and it was found that this would be feasible.

Therefore, the company began buying corrugated cardboard bobbins of the same width as the panels and doors, and the employee responsible for cutting the cardboard was instructed to cut it to the exact lengths of the manufactured pieces. Another instruction given to that employee regarding the use of corrugated cardboard addressed the case in which some cardboard was left at the end of the reel, i.e., a piece of a length not corresponding to either the panels or the doors. In this case, the employee should glue this piece of cardboard to another piece at the beginning of a new cardboard reel and then measure the length needed for the packaging of the product.

The preliminary feasibility study for this CP opportunity demonstrated an opportunity for a change in raw material, with low cost and simple implementation, where no other feasibility studies were necessary. It was observed that, after the implementation of this CP opportunity, for annual production of 448,800 panels and 76,200 doors for commercial rooms in this division, these changes achieved a saving of $4789 \mathrm{~kg}$ of corrugated cardboard (4789 kg no longer consumed, of which $499 \mathrm{~kg}$ was not generated as waste); see Table 2 .

The economic benefit obtained was US\$ 2138.00 a year, corresponding to the cost of purchasing $4789 \mathrm{~kg}$ of corrugated cardboard. The market value of the material was used as a reference to calculate the economic benefit, including freight but excluding recoverable taxes. As an environmental benefit, the consumption of natural resources (e.g., water, electric and thermal power, and wood) necessary for the manufacture of $4789 \mathrm{~kg}$ of corrugated cardboard was eliminated, in addition to the fuel that would be consumed in transporting the cardboard from the manufacturer to the company and that consumed in transporting the waste (no longer being generated) to its destination for disposal.

\subsection{Opportunity for reduction in the generation of rigid plastic tape waste in the packaging of panels and doors}

This CP opportunity was identified by using a balance sheet of materials for the paneling division, through an analysis of the inputs and outputs of rigid plastic tape used in the packaging of panels and doors. The panels and doors are sold as packages of 34unit stacks. These stacks are strapped with rigid plastic tape, which is bonded (fused) with pneumatic taping equipment. By observing the company's dumpsters, it was verified that there was a large volume of discarded thick rigid plastic tape that originated from raw material packaging in other divisions of the company. As a $\mathrm{CP}$ opportunity, the possibility of reusing this thick, rigid plastic tape was suggested, replacing the rigid plastic tape that was currently used for strapping. For this purpose, it was necessary to purchase an appropriate pneumatic taper to handle this thicker plastic tape.

Table 2

Benefits obtained from the reduction of surplus corrugated cardboard consumption.

\begin{tabular}{|c|c|c|c|c|}
\hline $\begin{array}{l}\text { Material } \\
\text { specifications }\end{array}$ & $\begin{array}{l}\text { Amount } \\
\text { consumed } \\
\text { (kg/year) }\end{array}$ & $\begin{array}{l}\text { Waste } \\
\text { specifications }\end{array}$ & $\begin{array}{l}\text { Amount } \\
\text { generated } \\
\text { (kg/year) }\end{array}$ & \\
\hline $\begin{array}{l}\text { Corrugated } \\
\text { cardboard }\end{array}$ & 39,160 & $\begin{array}{l}\text { Surplus } \\
\text { cardboard }\end{array}$ & 499 & Before $\mathrm{CP}$ \\
\hline $\begin{array}{l}\text { Corrugated } \\
\text { cardboard }\end{array}$ & 34,371 & $\begin{array}{l}\text { Surplus } \\
\text { cardboard }\end{array}$ & 0 & After CP \\
\hline $\begin{array}{l}\text { Corrugated } \\
\text { cardboard }\end{array}$ & 4789 & $\begin{array}{l}\text { Surplus } \\
\text { cardboard }\end{array}$ & 499 & $\begin{array}{l}\text { Benefit } \\
\text { obtained }\end{array}$ \\
\hline
\end{tabular}


When this CP opportunity was identified, it was requested that the purchasing division of the company solicits suppliers of pneumatic taping equipment and purchases a new taper compatible with the required procedure.

The preliminary feasibility study for this CP opportunity demonstrated that it was an opportunity that was simple to implement at a moderate cost, as it was based on a technological change involving the reuse of waste from the company itself. The technical feasibility study, performed with a pneumatic taper loaned for testing, demonstrated that the new equipment provided the required performance, meeting the operational needs for bonding the reused thicker rigid plastic tape. The economic feasibility study indicated that the calculated invested capital recovery period was 1.13 years, assuming an investment of US\$ 8333.00 for the purchase of a new pneumatic taper.

After the implementation of this $\mathrm{CP}$ measure, with an annual production of 448,800 panels and 76,200 doors, $2383 \mathrm{~kg}$ of rigid plastic tape was saved, and $11 \mathrm{~kg}$ of tape waste was no longer generated. Additionally, $2890 \mathrm{~kg}$ of the thicker rigid plastic tape was no longer wasted, and $18 \mathrm{~kg}$ of plastic and $24 \mathrm{~kg}$ of cardboard rolls for the plastic tape packaging were saved, as shown in Table 3. (The thicker rigid plastic tape, now being reused, has a mass per linear meter approximately $21 \%$ higher than that of the rigid plastic tape that was previously used).

After the end of the investment recovery period, a saving of US\$ 7381.00 was obtained, the amount previously spent on the purchase of $2383 \mathrm{~kg}$ of rigid plastic tape, as calculated from the market value of the material in US\$ $/ \mathrm{kg}$, including the freight and excluding recoverable taxes. As an environmental benefit, the savings in power, raw material and inputs used in the production of $2383 \mathrm{~kg}$ of rigid plastic tape that were previously consumed are highlighted. Also highlighted are the fuel savings for the transport of tape from the manufacturer to the company and for the delivery of $2900 \mathrm{~kg}$ of thick rigid tape discarded, in addition to the surplus plastic tape previously being consumed and the transport of $41 \mathrm{~kg}$ of plastic and cardboard rolls. Clearly, from an environmental viewpoint, the best use of the thick rigid plastic tape is its reuse for the same purpose.

Table 3

Benefits obtained from the reduction of rigid plastic tape waste generation.

\begin{tabular}{|c|c|c|c|c|}
\hline $\begin{array}{l}\text { Materials } \\
\text { specifications }\end{array}$ & $\begin{array}{l}\text { Amount } \\
\text { consumed } \\
\text { (kg/year) }\end{array}$ & $\begin{array}{l}\text { Waste } \\
\text { specifications }\end{array}$ & $\begin{array}{l}\text { Amount } \\
\text { generated } \\
(\mathrm{kg} / \text { year })\end{array}$ & \\
\hline \multirow[t]{4}{*}{$\begin{array}{l}\text { Rigid } \\
\text { plastic tape }\end{array}$} & \multirow[t]{4}{*}{2383} & $\begin{array}{l}\text { Surplus rigid } \\
\text { tape }\end{array}$ & 11 & \multirow[t]{4}{*}{ Before CP } \\
\hline & & $\begin{array}{l}\text { Cardboard } \\
\text { rolls } \\
\text { (packaging) }\end{array}$ & 24 & \\
\hline & & $\begin{array}{l}\text { Plastic } \\
\text { (packaging) }\end{array}$ & 18 & \\
\hline & & $\begin{array}{l}\text { Thick rigid } \\
\text { plastic tape } \\
\text { (from other } \\
\text { divisions) }\end{array}$ & 2890 & \\
\hline $\begin{array}{l}\text { Thicker rigid } \\
\text { plastic tape }\end{array}$ & 2890 & Nonexistent & 0 & After CP \\
\hline \multirow[t]{4}{*}{$\begin{array}{l}\text { Rigid } \\
\text { plastic tape }\end{array}$} & \multirow[t]{4}{*}{2383} & $\begin{array}{l}\text { Surplus rigid } \\
\text { tape }\end{array}$ & 11 & \multirow[t]{4}{*}{$\begin{array}{l}\text { Benefit } \\
\text { obtained }\end{array}$} \\
\hline & & $\begin{array}{l}\text { Cardboard } \\
\text { rolls } \\
\text { (packaging) }\end{array}$ & 24 & \\
\hline & & $\begin{array}{l}\text { Plastic } \\
\text { (packaging) }\end{array}$ & 18 & \\
\hline & & $\begin{array}{l}\text { Thick rigid } \\
\text { plastic tape } \\
\text { (from other } \\
\text { divisions) }\end{array}$ & 2890 & \\
\hline
\end{tabular}

3.3. Opportunity for the reduction of wood waste generated in the manufacturing of frames used in the production of doors and dividing panels

This CP opportunity was identified via the material balance sheet for the paneling division, through an analysis of the inputs and outputs of wooden boards used for the manufacturing of wood frames used in the construction of panels and doors. First, the boards are sawed transversally, the ends are removed, and they are cut to the proper length. Next, they are sawed longitudinally with a "multilayer" machine, consisting of a set of five saws, to produce the wood frame sections. Wood waste is created in both operations.

The possible causes for the generation of wood waste were analyzed during the operation of board cutting for frame manufacturing; most of the waste generation observed was due to the use of boards with excess width and length and to the thickness of the saw blades used in the multilayer machine. Therefore, to decrease the generation of wood waste, mainly the great volume of sawdust generated, it was necessary to replace the five saw blades used in the multilayer machine with thinner blades and to use boards with smaller dimensions. These two actions entailed the purchase of saws with thinner blades and boards with smaller dimensions. To provide further benefit from this opportunity, a request was made to the board supplier that the wood beams and the rigid plastic tape used in packaging of the boards be supplied with the appropriate dimensions for reuse as raw materials in other divisions of the company, such that they would no longer be wasted.

The preliminary feasibility study for this CP opportunity demonstrated that it was a relatively inexpensive opportunity of medium complexity, involving changes in raw material and technology. In the technical feasibility study, it was observed that the newly purchased saws had an adequate operational performance, meeting the technical requirements for cutting of the wooden boards. The economic feasibility study indicated that the calculated invested capital recovery period was 0.04 years, assuming an investment of US\$ 1785.00 for the purchase of new saws for the multilayer equipment.

After the implementation of this CP opportunity, for annual production of 448,800 panels and 76,200 doors, there was an annual reduction in the consumption of wooden boards of $300,091 \mathrm{~kg}$ and reductions of $286,792 \mathrm{~kg}$ in the generation of wood waste, $395 \mathrm{~kg}$ of rigid plastic tape and $10,370 \mathrm{~kg}$ of wooden beams. Regarding the last item, the surplus wooden beams used as packaging that were previously discarded were reused within the company, as listed in Table 4.

Table 4

Benefits obtained from the reduction of wood waste generation.

\begin{tabular}{|c|c|c|c|c|}
\hline $\begin{array}{l}\text { Material } \\
\text { specifications }\end{array}$ & $\begin{array}{l}\text { Amount } \\
\text { consumed } \\
\text { (kg/year) }\end{array}$ & Waste specifications & $\begin{array}{l}\text { Amount } \\
\text { generated } \\
\text { (kg/year) }\end{array}$ & \\
\hline $\begin{array}{l}\text { Wooden boards } \\
\text { with old } \\
\text { dimensions }\end{array}$ & $1,856,059$ & $\begin{array}{l}\text { Non-reusable rigid plastic } \\
\text { tape (board packaging) } \\
\text { Non-reusable wood beams } \\
\text { (board packaging) } \\
\text { Wood waste }\end{array}$ & $\begin{array}{r}362 \\
6594 \\
504,956\end{array}$ & Before $\mathrm{CP}$ \\
\hline $\begin{array}{l}\text { Wooden boards } \\
\text { with new } \\
\text { dimensions }\end{array}$ & $1,555,968$ & $\begin{array}{l}\text { Reusable rigid plastic tape } \\
\text { (board packaging) } \\
\text { Reusable wood beams } \\
\text { (board packaging) } \\
\text { Wood waste }\end{array}$ & $\begin{array}{r}395 \\
10,370 \\
218,165\end{array}$ & After CP \\
\hline $\begin{array}{l}\text { Wooden boards } \\
\text { with old } \\
\text { dimensions }\end{array}$ & 300,091 & $\begin{array}{l}\text { Reusable rigid plastic tape } \\
\text { (board packaging) } \\
\text { Reusable wood beams } \\
\text { (board packaging) } \\
\text { Wood waste }\end{array}$ & $\begin{array}{r}395 \\
10,370 \\
286,792\end{array}$ & $\begin{array}{l}\text { Benefits } \\
\text { obtained }\end{array}$ \\
\hline
\end{tabular}


As an economic benefit, after the investment recovery period, gains equivalent to US\$45,542.00 a year were obtained due to a decrease in the consumption of wooden boards of $300,091 \mathrm{~kg}$ and due to the reuse of $395 \mathrm{~kg}$ of rigid plastic tape and of $10,370 \mathrm{~kg}$ of wooden beams in other divisions of the company. For these calculations, the market values of these materials were considered in US\$/kg, including the freight value and excluding recoverable taxes. Also considered in calculating the economic benefit of this opportunity was the annual income lost from the sale of 293,386 kg of wood waste, which was usually sold to the ceramics industry for use as fuel in their ovens.

As environmental benefits, the savings in power, raw materials, and necessary inputs for the manufacturing of $395 \mathrm{~kg}$ of rigid plastic tape that was previously consumed, the fuel used for its transport from the manufacturer to the company and the delivery of $362 \mathrm{~kg}$ of plastic tape waste that was previously generated are highlighted. Other environmental benefits include a reduction in the consumption of wooden boards and beams by $310,461 \mathrm{~kg}$ and $293,386 \mathrm{~kg}$ of wood waste that was no longer generated. Furthermore, indirect environmental gains include the reduction in the tree harvesting required to supply $310,461 \mathrm{~kg}$ of wood annually and the fuel savings for transporting the wooden boards and beams that are no longer consumed $(310,461 \mathrm{~kg})$ and the wood and beam wastes that are no longer generated $(293,386 \mathrm{~kg})$.

\subsection{Opportunity for reductions of effluent generation for the ETEI of the paneling division and of chemical product consumption for the treatment of this effluent}

This CP opportunity was identified via the material balance sheet prepared for the paneling division, through analyzing the amount of water as an input, and liquid effluent to the industrial effluent treatment station (ETEI) and the chemical products consumed in effluent treatment as outputs. In the production of panels and doors, water is used for manufacturing glue and for cleaning the glue station (where the glue mix is processed) and the "gluing" equipment. Glue is used to assemble panels and doors and is produced from a mixture of resin, wheat flour, catalyst and water. This water comes from a phreatic well installed at the manufacturing location and from the ETEI, through a reuse of the water produced by effluent treatment in that station. The company has rights to water use issued by the Water Management Institute of Minas Gerais (IGAM).

During the implementation of the $\mathrm{CP}$ program, it was observed that the employees of the paneling division repeatedly complained about inefficient operation of the ETEI, which prevented the total reuse of water from the treated effluent. It was demonstrated that the physical-chemical treatment applied to the emitted liquid effluent was not very efficient. In meetings with the CP team of the paneling division, the difficulties identified in effluent treatment in the ETEI were discussed along with possible solutions for the problem. One of the proposed solutions, which was considered one that would definitively solve the problem, was the purchase and installation of a new ETEI for effluent treatment, with an efficiency project to ensure the quality of the treated effluent according to the required environmental disposal standards.

By analyzing the balance sheet of materials and water for this division, especially the volume of water consumed and effluent emitted, another CP opportunity was identified. It was observed that the daily liquid effluent volume emitted due to cleaning of the gluing equipment was much greater than the volume of water consumed in glue manufacturing, where this illustrated the difficulty of developing an efficient treatment of the effluent in the ETEI. Therefore, the purchase of a high-pressure washer was proposed to make cleaning more efficient in the division and to reduce water consumption, thus decreasing the volume of effluent emitted to a level lower than the volume of water consumed in glue manufacturing and thus restoring the ETEl's capacity for treating the liquid effluent emitted by the paneling division.

The preliminary feasibility study for this CP opportunity showed that it was a simple and inexpensive opportunity, involving a technological change and improved operational practices, for which technical, economic and environmental feasibility studies were conducted. The technical feasibility study was limited to the choice of purchasing a high-pressure washer suitable for the cleaning service of the division. The equipment requirements were that a sufficient working pressure and water flow be provided for appropriate cleaning of the equipment of the paneling division and that the volume of liquid effluent emitted daily not be higher than the water volume consumed in glue manufacturing. The studies conducted after the purchase and use of this new equipment showed that the daily volumes of liquid effluents emitted were drastically reduced and that, due to the greater recycling of treated water in the ETEI, the use of chemical products previously employed for effluent treatment in the station was no longer necessary. The economic feasibility study showed that the calculated invested capital recovery period was 0.48 years, with an investment of US\$ 1226.00 for the purchase of a high-pressure washer.

After the implementation of this CP program, for annual production of 448,800 panels and 76,200 doors, a reduction of $200 \mathrm{~m}^{3}$ of water consumption was achieved, with a consequent reduction of the same amount of liquid effluent emitted and sent to the ETEI. Additionally, $356 \mathrm{~kg}$ of chemical products that was previously used for effluent treatment in the station was saved annually, as shown in Table 5.

As an economic benefit, after the recovery period for the investment had passed, an annual gain of US\$2539.00 was obtained, which corresponds to the sum of the costs saved by the reduced water consumption $\left(200 \mathrm{~m}^{3}\right)$ from the phreatic well and the purchase of $356 \mathrm{~kg}$ of chemical products. In these calculations, the cost per cubic meter of water from the phreatic well pumped into the factory and the market value of the previously purchased chemical products, in US\$ per kilogram, including the freight and excluding recoverable taxes, were used. It was also noted that a secondary economic benefit obtained was elimination of the need for a new effluent treatment station, at the budgeted cost of US\$ $65,477.00$, and that there was a reduced possibility of the occurrence of infraction notices and fines by the environmental regulating agency due to the total reuse of treated effluent within the factory.

Table 5

The economic and environmental benefits obtained from the reductions in effluent emissions and consumption of chemical products.

\begin{tabular}{|c|c|c|c|c|}
\hline $\begin{array}{l}\text { Material } \\
\text { specifications }\end{array}$ & $\begin{array}{l}\text { Amount } \\
\text { consumed ( } \mathrm{m}^{3} / \text { year } \\
\text { and } \mathrm{kg} / \text { year })\end{array}$ & $\begin{array}{l}\text { Effluent } \\
\text { specifications }\end{array}$ & $\begin{array}{l}\text { Amount } \\
\text { emitted } \\
\left(\mathrm{m}^{3} / \text { year }\right)\end{array}$ & \\
\hline $\begin{array}{l}\text { Water from } \\
\text { phreatic well }\end{array}$ & $310 \mathrm{~m}^{3}$ & $\begin{array}{l}\text { Paneling } \\
\text { effluent }\end{array}$ & $200 \mathrm{~m}^{3}$ & Before $\mathrm{CP}$ \\
\hline $\begin{array}{l}\text { ETEI chemical } \\
\text { products }\end{array}$ & $356 \mathrm{~kg}$ & & & \\
\hline $\begin{array}{l}\text { Water from } \\
\text { artisan well }\end{array}$ & $100 \mathrm{~m}^{3}$ & $\begin{array}{l}\text { Paneling } \\
\text { effluent }\end{array}$ & $0 \mathrm{~m}^{3}$ & After $\mathrm{CP}$ \\
\hline $\begin{array}{l}\text { ETEI chemical } \\
\text { products }\end{array}$ & $0 \mathrm{~kg}$ & & & \\
\hline $\begin{array}{l}\text { Water from } \\
\text { artisan well }\end{array}$ & $200 \mathrm{~m}^{3}$ & $\begin{array}{l}\text { Paneling } \\
\text { effluent }\end{array}$ & $200 \mathrm{~m}^{3}$ & $\begin{array}{l}\text { Benefit } \\
\text { obtained }\end{array}$ \\
\hline $\begin{array}{l}\text { ETEI chemical } \\
\text { products }\end{array}$ & $356 \mathrm{~kg}$ & & & \\
\hline
\end{tabular}


As an environmental benefit, the reduction in water consumption from the phreatic well of $200 \mathrm{~m}^{3}$ is highlighted, as well as the discontinued use of $356 \mathrm{~kg}$ of chemical products, providing reductions in handling risks and environmental contamination as a consequence of their use.

\subsection{Opportunity for the reduction of mud generation in the ETEI of the paneling division}

This CP opportunity was identified via the material balance sheet prepared for the paneling division by analyzing the quantified output of mud generated in the ETEI. The glue consumed in the production of panels and doors is prepared, as mentioned before, at the glue station and is made available for use through the "gluing" equipment. The ETEI of the paneling division receives only the effluent coming from the cleaning of the glue kitchen and the gluing equipment; therefore, this is the fraction that is decanted at the treatment station and transformed into mud, originating exclusively from the prepared glue that was not used in the manufacturing process.

During the meetings conducted with the CP team, where the sources and possible causes of the huge generation of mud in the ETEI were discussed, it was concluded that most of it did not come from cleaning of the glue kitchen equipment and the gluing equipment but rather from glue that was disposed of before being used on the production line. It was also concluded that, during glue production and in the assembly and gluing of panels and doors, there were no controls or standards for operational processes; i.e., the operations were conducted based only on the experience of the employees in the division. It was found that a lack of good production practices and appropriate controls at the glue manufacturing site were the main causes of glue waste and, consequently, of mud generation in the ETEI.

As actions proposed for this CP opportunity, documents for the standardization of operational practices used in glue manufacturing and in the gluing of panels and doors were prepared; laboratory tests were also introduced for quality analysis of the produced glue and the raw materials used. Laboratory tools and equipment were purchased for use during glue preparation to decrease the generation of glue waste.

The feasibility study for this CP opportunity showed that it was an opportunity of average complexity with low cost, involving changes in operational practices, for which technical, economic and environmental feasibility studies were conducted. The technical feasibility study demonstrated that this CP opportunity, among the five discussed in this study, required the most training for employees because it was mainly concerned with the adoption of good operating practices and training for the routine accomplishment of laboratory tests of the raw materials used and of the glue itself. The economic feasibility study indicated that the calculated invested capital recovery period was 0.10 years, with an investment of US\$ 1785.00 in laboratory tools and equipment and training for the relevant employees.

After the implementation of this $\mathrm{CP}$ program, for annual production of 448,800 panels and 76,200 doors, a reduction of $24,279 \mathrm{~kg}$ in the generation of mud in the ETEI was obtained, as shown in Table 6 . As an economic benefit, after the investment recovery period, an annual saving of US\$ $14,568.00$ was obtained by eliminating glue waste, with a consequent reduction in the generation of mud in the ETEI, based on equating the value of a kilogram of mud to that of a kilogram of glue, i.e., US\$ 0.60/ $\mathrm{kg}$ (for values from December 2010). Another economic benefit was related to the disposal cost of the generated mud. The annual cost estimated for the transport and disposal of $24,279 \mathrm{~kg}$ of mud in landfills was US\$ 2913.00 (US\$ 120.00/t, at the December 2010
Table 6

The economic and environmental benefits obtained from the reduction in mud generation at the ETEI.

\begin{tabular}{lllll}
\hline $\begin{array}{l}\text { Material } \\
\text { specifications }\end{array}$ & $\begin{array}{l}\text { Amount } \\
\text { received } \\
\text { (kg/year) }\end{array}$ & $\begin{array}{l}\text { Waste } \\
\text { specifications }\end{array}$ & $\begin{array}{l}\text { Amount } \\
\text { emitted } \\
\text { (kg/year) }\end{array}$ & \\
\hline $\begin{array}{c}\text { Effluent } \\
\text { (water }+ \text { glue) }\end{array}$ & Not quantified & ETEI Mud & 45,236 & Before CP \\
$\begin{array}{c}\text { Effluent } \\
\text { (water }+ \text { glue) } \\
\text { Effluent } \\
\text { (water }+ \text { glue) }\end{array}$ & Not quantified & ETEI Mud & 20,957 & After CP \\
& ETEI Mud & 24,279 & $\begin{array}{l}\text { Benefit } \\
\text { obtained }\end{array}$ \\
\hline
\end{tabular}

a Quantification made only for glue (using the estimated composition of $4 \mathrm{~m}^{3}$ of water $+20,079 \mathrm{~kg}$ of resin, catalyst and wheat flour).

price). According to an analytic report by a laboratory accredited by the Brazilian National Standards Organization (ABNT), using the standard for solid waste classification (ABNT NBR 10004), which classifies solid wastes according to hazard risk, considering its potential risks to the environment and public health, so that they can be properly managed, the generated mud has a II A classification, i.e., a nonhazardous and non-inert material.

As environmental benefits, annual savings in water consumption from the phreatic well and in raw materials used in glue manufacturing were obtained in proportion to the $24,279 \mathrm{~kg}$ of mud that was no longer being generated. It is also important to consider the reductions in power consumption, raw materials and inputs necessary for the production of the materials that constituted this saved glue and the power used for pumping water from the phreatic well that was no longer consumed. Another environmental benefit obtained relates to the elimination of storage, transport and landfill disposal operations for the mud from the ETEI, resulting in the expansion of the useful life of landfills and reductions in fuel consumption for its transport and the risk of environmental accidents during handling.

\subsection{Overall results obtained in the paneling division with $C P$ programs}

The environmental and economic benefits that were obtained with the implementation of the five $\mathrm{CP}$ programs in the paneling division of the Mod Line factory after the financial investments recovery periods are compiled in Table 7 .

The comparison between the data in Table 1 and the results in Table 7 reveals the gains: (1) an economy of $327,699 \mathrm{~kg}$ in materials, which represents $3 \%$ of the annual consumption in the paneling division, (2) a saving of $204 \mathrm{~m}^{3}$ in water, which represents $66 \%$ of the total that had been used up annually, (3) a reduction of $325,277 \mathrm{~kg}$ in solid waste generation, which represents $23 \%$ of the refuses produced every year before the CP program, (4) a decrease of $200 \mathrm{~m}^{3}$ in effluents, which represents $93 \%$ of the previous annual emissions.

The global financial investment was around US\$ 13,130.00, and the payback on it was longer than a year only in the case of reduction in the generation of rigid plastic tape waste in the packaging of panels and doors. The total annual return was around US\$ 75,100.00; considering that 448,880 panels and 76,200 doors were manufactured, it means an average lessening of production costs of US\$ 0.14 per unit.

Another indicator is the number of adult trees cut down in order to meet the demand for materials. It took into account two aspects. First, the reduction in the amount of corrugated cardboard used: according to the Brazilian Association of Pulp and Paper every $1000 \mathrm{~kg}$ of that paper requires 15 mature trees, since Mod Line could save $4789 \mathrm{~kg}$ of corrugated cardboard annually, 72 adult trees 
Table 7

Summary of the economic and environmental benefits obtained from the implementation of actions addressing the five CP opportunities.

\begin{tabular}{|c|c|c|c|c|c|}
\hline CP opportunities addressed & $\begin{array}{l}\text { Environmental benefits: } \\
\text { annual savings in } \\
\text { material }(\mathrm{kg}) \text { and } \\
\text { water consumption }\left(\mathrm{m}^{3}\right)\end{array}$ & $\begin{array}{l}\text { Environmental benefits: } \\
\text { nongeneration of annual } \\
\text { solid wastes }(\mathrm{kg}) \text { and } \\
\text { of liquid effluents }\left(\mathrm{m}^{3}\right)\end{array}$ & $\begin{array}{l}\text { Investment needed for the } \\
\text { implementation of the CP } \\
\text { opportunity (US\$) }\end{array}$ & $\begin{array}{l}\text { Recovery period } \\
\text { (RP) for the } \\
\text { invested capital } \\
\text { (year) }\end{array}$ & $\begin{array}{l}\text { Economic } \\
\text { benefit } \\
\text { obtained } \\
\text { after the } \\
\text { RP (US\$/year) }\end{array}$ \\
\hline $\begin{array}{l}\text { Opportunity for reduction } \\
\text { of surplus corrugated } \\
\text { cardboard generation }\end{array}$ & $4789 \mathrm{~kg}$ & $498 \mathrm{~kg}$ & - & - & 2138.00 \\
\hline $\begin{array}{l}\text { Opportunity for reduction of } \\
\text { rigid plastic tape waste } \\
\text { generation }\end{array}$ & $2383 \mathrm{~kg}$ & $2942 \mathrm{~kg}$ & $8.333,00$ & 1.13 & 7381.00 \\
\hline $\begin{array}{l}\text { Opportunity for reduction } \\
\text { of wood waste generation }\end{array}$ & $300,091 \mathrm{~kg}$ & $297,557 \mathrm{~kg}$ & $1.785,00$ & 0.04 & $45,542.00$ \\
\hline $\begin{array}{l}\text { Opportunity for reductions } \\
\text { of effluent generation and } \\
\text { the consumption of } \\
\text { chemical products }\end{array}$ & $356 \mathrm{~kg}\left(200 \mathrm{~m}^{3}\right)$ & $200 \mathrm{~m}^{3}$ & $1.226,00$ & 1.00 & 2560.00 \\
\hline $\begin{array}{l}\text { Opportunity for reduction } \\
\text { of ETEI mud generation }\end{array}$ & $20,079 \mathrm{~kg}\left(4 \mathrm{~m}^{3}\right)$ & $24,279 \mathrm{~kg}$ & 1785.00 & 0.10 & $17,481.00$ \\
\hline Grand total & $327,699 \mathrm{~kg}\left(204 \mathrm{~m}^{3}\right)$ & $325,277 \mathrm{~kg}\left(200 \mathrm{~m}^{3}\right)$ & $13,129.00$ & - & $75,102.00$ \\
\hline
\end{tabular}

per year will no longer be cut, at least not for that purpose. Second, the diminution in the wood consumption in the manufacture of doors and partition panels: $518 \mathrm{~m}^{3}$ less wood implies 3851 more standing pine trees.

The last indicator is the reduction in the greenhouse gases (GHG) emissions, which is a consequence of the reduction in the need of transport and therefore, in diesel oil consumption. The CP program in Mod Line could prevent $13,100 \mathrm{~kg}$ of carbon dioxide equivalent emissions.

To calculate the reduction in carbon dioxide equivalent emissions, an average distance from the material distributors and suppliers to the Mod Line factory equal to $500 \mathrm{~km}$ and an average distance from the Mod Line factory to the waste disposal places equal to $40 \mathrm{~km}$ were considered. Since the trucks can carry approximately $27,000 \mathrm{~kg}$ of materials or waste, the total distance traveled yearly is around $6550 \mathrm{~km}$. Moreover, we assume that $1 \mathrm{~L}$ of diesel oil emits $1.4 \mathrm{~kg}$ of carbon dioxide equivalent to the atmosphere (Soares et al., 2009) and that the average consumption of fuel is around $2 \mathrm{~km} \mathrm{~L}^{-1}$.

In order to obtain a significant environmental benefit, the $\mathrm{CP}$ actions implemented in Mod Line factory, which has only $15 \%$ of Brazilian doors and partition panels market, could be extended to almost all wooden furniture industries in Brazil, since their manufacturing processes are very similar.

\section{Conclusions}

$\mathrm{CP}$ programs are a powerful tool in the quest for eco-efficiency, as they can result in big reductions in both material, water waste, and energy wastage.

Identifying $\mathrm{CP}$ opportunities within the manufacture processes and implementing them at the start of the industrial operation shall minimize environmental impacts and financial losses in the near future. Moreover, the continuity of the program should be easier because the company's senior managers and the $\mathrm{CP}$ team were more motivated and confident about the positive results of the $\mathrm{CP}$ program.

The CP methodology allies financial gains with environmental protection, which is a crucial factor to its adoption by the companies in general and by Mod Line in particular.

Throughout this study, it was observed that there was an increase in the environmental awareness of the paneling division employees and the industry managers. Currently, Mod Line has an environment department and is working to implement more sustainable $\mathrm{CP}$ productions practices in all manufacture divisions.

In order to support on-going progress in the implementation of $\mathrm{CP}$, at least one person that knows $\mathrm{CP}$ processes, the concepts and the phases should be appointed in order to fulfill the program, to lead the CP team, the employees and the managers, to monitor the $\mathrm{CP}$ program development, and to report on improvements and accomplishments.

Another important element for the successful implementation of a CP methodology in a company is the choice of an appropriate index for material and water consumption or of the emissions of solid waste and liquid effluent on a production basis, with which the monitoring and the verification of the results of CP application can be conducted. The importance of such indices is related to obtaining information about "how things are really working", and their use is an excellent way of motivating employees to take part in the actions prescribed in CP programs. In this study, it was observed that it was mainly after the adoption of index spreadsheets on the emission and consumption of materials, for example, for mud generation in the ETEI and water consumption due to panel and door production, and the monthly follow-up of results recorded in those spreadsheets, that the engagement of employees adopting new production practices in the paneling division resulted in better performance.

\section{References}

CEPIS-Sustainable Production Center, 2007. Presentation: Where We Are. Available at: http://www.cepis.org.br/apresentacao/ (accessed 05.02.09.).

CETESB/UNEP, 2002. Status Report: Cleaner Production in Latin America and the Caribbean. CETESB, UNEP, São Paulo, Paris.

Daian, G., Ozarska, B., 2009. Wood waste management practices and strategies to increase sustainability standards in the Australian wooden furniture manufacturing sector. J. Clean. Prod. 17, 1594-1602.

Eco Inspector, 2006. Eco Inspector Plus. Available at: http://www.ecoinspector.ch/ new/index.php?layout=leistung (accessed 20.10.09.).

Ehrenfeld, J., Gertler, N., 1997. Industrial ecology in practice. The evolution of interdependence at Kalundborg. J. Ind. Ecol. 1 (1), 67-80.

Eshun, J.F., Potting, J., Leemans, R., 2012. Wood waste minimization in the timber sector of Ghana: a systems approach to reduce environmental impact. J. Clean. Prod. 26, 67-78.

Germany Federal Environment Ministry, 1997. A Guide to Corporate Environment Indicators. Mod Line Corporate Solutions Ltd., Bonn, p. 47. Personal communication.

Nascimento, N.C., 2009. Generation of Solid Waste in an Industry of Mobile Medium. University of Ribeirão Preto, Ribeirão Preto, p. 114.

Oliveira, M., Araújo, F.A., 2009. The cleaner production applied in a small industry of the furniture sector: environmental and economic efficiency. 2 nd 
International Workshop Advances in Cleaner Production. São Paulo, Brazil, May 20th-22th.

Riul, M., 2010. Diagnosis and Guidelines for Managing Social and Environmental Aspects in APL Furniture João Pessoa - PB. Graduate Program in Environmental Development - PRODEMA - Federal University of Paraiba, João Pessoa, p. 245.

Schnitzer, H., 1995. ECOPROFIT. Graz University of Technology, Austria.

Soares, L.H.B., Alves, B.J.R., Urquiaga, S., Boddey, R.M., 2009. Mitigation of Emissions of Greenhouse Gases by the Use of Ethanol from Sugar Cane Produced in Brazil.
MAPA, EMBRAPA, Rio de Janeiro. Available at: http://www.cnpab.embrapa.br/ publicacoes/circular_tec.html (accessed 12.01.10.).

UNIDO/UNEP, 1991. Audit and Reduction Manual for Industrial Emissions and Waste. Publication, Technical Report Series N. 7. United Nations Publication, Paris. UNIDO/UNEP, 1995. Guidance Materials for the UNIDO/UNEP National Cleaner

Production Centres. United Nations Environment Programme, Paris, France.

Vickery, S.K., Dröge, C., Markland, R.E., 1997. Dimensions of manufacturing strength in the furniture industry. J. Oper. Manag. 15, 317-330. 